\title{
Antibacterial activity and phytochemical screening of ethanolic leaf, stem and flower extract of Aerva lanata
}

\author{
S. Nimisha \\ Department of Microbiology, Malankara Catholic College, Mariagiri, Kannyakumari (Tamil \\ Nadu), India \\ K.R. Beula Rani* \\ Department of Microbiology, Malankara Catholic College, Mariagiri, Kannyakumari (Tamil \\ Nadu), India \\ ${ }^{*}$ Corresponding author. E-mail:krbr609@gmail.com

\begin{abstract}
Screening of phytochemicals provides the potentiality for serving several illnesses. The current investigation was carried out the antibacterial activity and phytochemical screening of ethanolic extract of leaf, flower and stem of Aerva lanata commonly known as Sirupeelai through spectroscopic analysis. In this screening the major components are carbohyrates, aminoacids, alkaloids, flavonoids, phenols, terpenoids and cocumarins. The antibacterial activity showed maximum sensitivity in leaf extract of Staphylococcus aureus $(16 \mathrm{~mm})$. The FTIR spectroscopic analysis revealed that the functional groups were alkene, alkyne, amines which showed major peaks. Based on antibacterial activity and functional group analysis, GC-MS was carried out in leaf extract of $A$. lanata. The current report indicated 27 bioactive compounds, in that Uridine is a major peak which showed antibacterial, anti-inflammatory, anti-diabetic, anti-cancerous activity etc.
\end{abstract}

Keywords: Aerva lanata, Antibacterial, FTIR, GC-MS, Phytochemical, Staphylococcus aureus.

\section{INTRODUCTION}

The plant kingdom was treated as the benefit for diverse variety of potentialities. Earlier, many diseases were treated using plant derived secondary components (Gullo et al., 2005). Abundantly $80 \%$ of drugs are derived from plant products. These medicinal plants contain convinced phytochemical compounds which serve as disorder for the infective diseases like bacterial, fungal, and viral and cancer disorders (Krishnamoorthi et al., 2015).

The use of plant derived products can diminish negative impacts and the compounds present in plants have preventive consequence against many pathogenic microorganisms (Desai et al., 2008). Nearly all medicinal plants have immense potentiality for detection of new drugs of asset to humanity. Recently, a lot of approaches are reached for advanced active components in the medicinal herbs onto the production of secured medicines. The phytochemical components of the plants can cure human illness and these components are not toxic and consequently they are eco -friendly (Nostro et al., 2000). The chief metabolic compounds create phytochemicals. The main components are common sugars, protein and chlorophyll, and the minor components comprised of alkaloids, flavonoids, terpenoids, phenolic compounds, tannins, glycosides, gums and essential oils (Krishnaiah et al., 2007).

Aerva lanata is a medicinal herb reside the family Amaranthaceae. It is one of the plants counted in Dasapushpam, "the ten sacred flowers of Kerala". The plant is used as food for people and animals. The whole plant, mainly the leaves are consumable as spinach. It has very rich pharmacological properties such as "anthelmintic, demulcent, antiinflammatory, diuretic, expectorant, hepatoprotective, nephroprotective anti-diabetic activity, antihyperglycaemic activity in rats, antimicrobial, cytotoxic, urolithiatic, hypoglycemic, antihyperlipidaemic, anti-parasitic, anti-helmentic and antioxidant activities" (Muthukumaran et al.,2011). The plant is treated as a conventional medicine meant for snakebites. The crushed juice of $A$. lanata root is treated for jaundice therapy. It aids in controlling the blood glucose level. It is also a good herbal cure for stones in urinary bladder and kidney (Vijayakumar et al., 1998)

Hence the present research was initiated to study the antibacterial activity and phytochemical characterization of the ethanolic extracts of medicinal plant $A$. lanata for their therapeutic potential. 
Nimisha, S. and Rani, K.R.B. / J. Appl. \& Nat. Sci. 11(2): 455 - 461 (2019)

\section{MATERIALS AND METHODS}

Description of the study site: Karode, a village situated in Parassala Block within Thiruvananthapuram District of Kerala State, India. It resides to South Kerala Division. It is situated $30 \mathrm{~km}$ towards East from District headquarters Thiruvananthapuram and $3 \mathrm{~km}$ from Parassala, $30 \mathrm{~km}$ from State capital Thiruvananthapuram. It is close to the Tamil Nadu State border. It is nearby to Arabian sea. There is a chance of humidity in the weather. This place contains rich diversity of medicinal plants (Fig. 1). The plant $A$. lanata is commonly known as Sirupeelai in Tamil language, Cherula in Malayalam belongs to the family of Amaranthaceae (Fig.2). It is an erect herbaceous weed found all over in India.

A. lanata was collected from the natural habitats at karode, Thriuvanthapuram district, Kerala, India. The plants were identified and authenticated by NMC college herbarium, Marthandam, Tamil Nadu, India.

Preparation of leaf extracts: The freshly collected leaf, flower and stem samples were cleaned completely with distilled water and shade dried at room temperature for 30 - 45 days. Following drying, the samples were beached into fine debris using an electric blender then filtered using muslin cloth and were stored in air tight containers at ambient temperature until required. The finely powdered samples of $10 \mathrm{gm}$. were soaked in 100 $\mathrm{ml}$ of ethanol in $200 \mathrm{ml}$ sterile conical flask. The flask were covered with aluminium foil and kept for $48 \mathrm{hrs}$. at room temperature. Then it was filtered by using Whatman NO.1 filter paper. This extract was used for supplementary examination.

Determination of minimum inhibitory concentration (MIC): The antimicrobial activity of the extracts was evaluated by using well diffusion assay. $20 \mathrm{ml}$ sterile Muller Hinton agar was flooded into petridishes and enabled for gelatination. The 24 hours pathogenic bacterial cultures were grown in nutrient broth such as

Escherichia coli and Staphylococcus aureus, Pseudomonas aeruginosa, Bacillus subtilis and Klebsiella pneumonia were seeded aseptically on the respective agar plates using cotton swab. Then $6 \mathrm{~mm}$ diameter well was punched on the top of the agar plate using a sterile gel puncher. $50 \mu \mathrm{l}$ of ethanolic leaf extract was filled into the wells and the plates were incubated at $37^{\circ} \mathrm{C}$ for 24 hours. Following incubation the diameter of zone inhibition found throught every well measured and expressed in millimeters $(\mathrm{mm})$.

The minimum inhibitory concentration (MIC) of ethanolic leaf, flower and stem extracts of $A$. lanata with respect to $S$. aureus was determined by broth dilution method.10 test tubes were taken and add nutrient broth in first and last tube contain $1.6 \mathrm{ml}$ and all other tubes were added with $0.9 \mathrm{ml}$ nutrient broth. In the first and last test tubes added
$200 \mu$ l extracts and $200 \mu \mathrm{l}$ of DMSO solution and mix well. Then transfer $0.9 \mu \mathrm{l}$ from the first tube to second and serially diluted till eight tubes and discard $0.9 \mathrm{ml}$ from eighth tube. The ninth tube contain only nutrient broth (control). Then add $100 \mu \mathrm{l}$ of $10-24$ hours $S$. aureus in all tubes till eighth. The tubes were incubated at $37^{\circ} \mathrm{C}$ for $18-24$ hours. After incubation $100 \mu \mathrm{l}$ from first 3 to 4 tubes were sub cultured separately on Muller Hinton agar plates and incubated at $37^{\circ} \mathrm{C}$ for 24 hours. The volume remained in the tubes after sub culturing were again added with $20 \mu$ of resazurin dye and incubated at $37^{\circ} \mathrm{C}$ for $6-8$ hours(Das et al.,2013).

Determination of minimal bactericidal concentration (MBC): The MBC of leaf, flower and stem extracts were conceived by counter culturing $10 \mu \mathrm{l}$ of the test concentration from MIC tubes on to Muller Hinton agar plates. Cultured plates were then fostered at $37^{\circ} \mathrm{C}$ for 24 hours. The highest intensity that prompted little or negative bacterial colony on the plates were documented as MBC (Pavithra et al., 2010).

Phytochemical analysis: Phytochemical analysis of ethanolic extract of leaf, stem and flower for alkaloids (Wagner's test and Dragendorff's test), carbohydrates (Benedict's test, Fehling's test and Barfoed's test), aminoacids (Ninhydrin test), protein (Biuret test), flavonoids(Lead acetate test), phenols (Ferric chloride test and Lead acetate test), tannin, saponin, terpenoids and cocumarins was carried out to determine the presence of chemical compounds using the standard qualitative procedures (Sofowra, 1993; Harborne, 1998).

Fourier transform nfrared spectroscopic analysis (FTIR): FTIR analysis was carried out to reveal the functional group of the plant extract. Based on the sensitivity pattern of antibacterial studies FTIR was performed only in leaf extract. The dried $2 \mathrm{mg}$ leaf sample was mixed in the 100 mg KBR (FTIR grade) and then compressed to prepare salt disc the disk was medially kept in the sample holder and FTIR spectra were documented in the absorbance range between 1000 and $3500 \mathrm{~cm}^{-1}$. All perusals were procured with a Shimdzu FTIR spectrometer.

Gas chromatography coupled with Mass spectroscopy (GC-MS): In order to determine the bioactive compound present in the leaf extract the experiment was performed in the Gas Chromatograph: A Shimdzu GC-2010 Plus gas chromatograph was assembled with a properly neutralised $2 \mathrm{~mm}$ direct injector liner and a 15m Alltech EC-5 column with a consistency of $250 \mu$ I.D., $0.25 \mu$. A split injection was adopted for sample initiation and the split ratio was set to $10: 1$. The oven temperature was pre-set to start at $35^{\circ} \mathrm{C}$, retain for 2 minutes, at the rate of $20^{\circ} \mathrm{C}$ per minute to $450^{\circ} \mathrm{C}$ and retain for 5 minutes. Helium was used as a carrier gas was set to $2 \mathrm{ml} /$ minute flow rate and 
Nimisha, S. and Rani, K.R.B. / J. Appl. \& Nat. Sci. 11(2): 455 - 461 (2019)
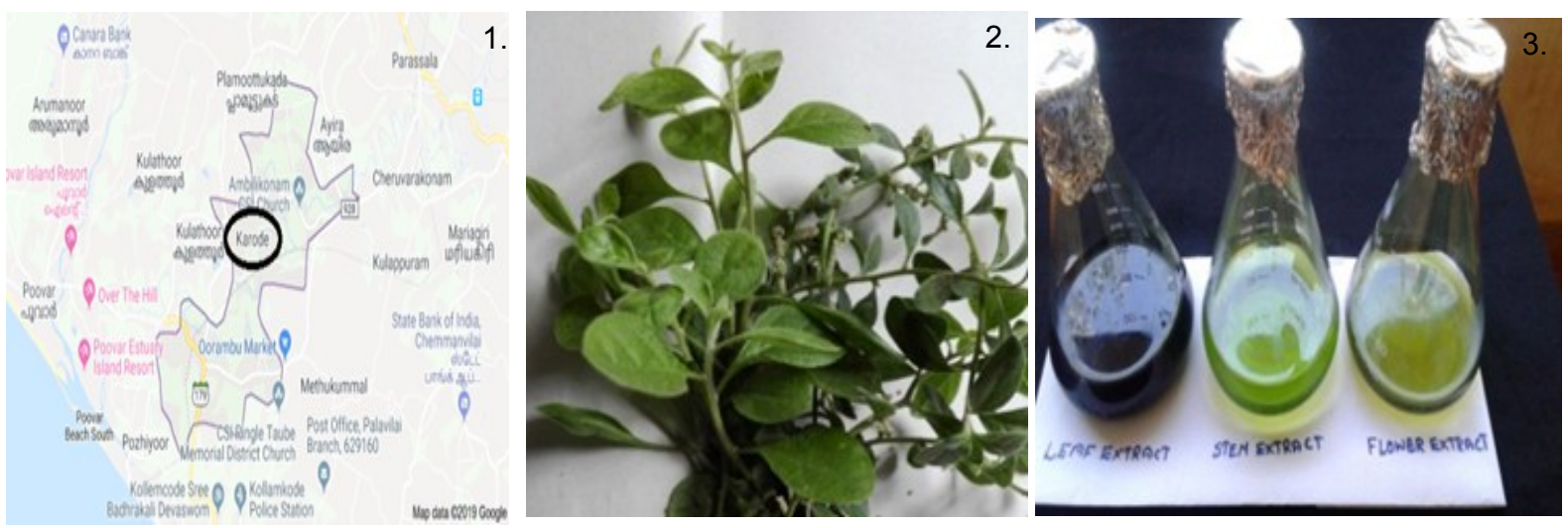

Figs. 1-3. 1. Map showing the study site Karode, 2. Plant A. lanata, 3 Leaf, stem and flower extracts of $A$. lanata.

the findings of the components were corresponding their documented spectra with the data bank mass spectra of NIST library $V 11$ maintained by the instruments software. GC/MS metabolomics Database was used for the similarity search with retention index. The components were recognized by gas chromatography coupled with mass spectrometry.

\section{RESULTS}

Phytochemical screening: The qualitative screening of phytochemical constituents for the plant extracts of $A$. lanata indicated that the ethanolic extracts of leaf samples were positive for flavonoids and phenols. The ethanolic extract of stem sample showed positive for carbohydrates, alkaloids, flavonoids, phenol, terpenoids and cocumarins. And the ethanolic extract of flower was positive for aminoacids, alkaloids, flavonoids, phenol and terpenoids. The results of different extracts (Fig.3) and phytochemical analysis are shown Table 1 and Fig. 4.

Antibacterial activity: In this study, the leaf sample of ethanol extract showed inhibitory activity against $S$. aureus $(16 \pm 0.2 \mathrm{~mm})$ E.coli $(14 \pm 0.2$ $\mathrm{mm}), B$. subtilis (12 $\pm 0.5 \mathrm{~mm}), P$. auriginosa, (11 $\pm 0.2 \mathrm{~mm}), K$. pneumonia $(10 \pm 0.2 \mathrm{~mm})$, and the stem sample showed inhibitory activity against $S$. aureus $(11 \pm 0.3 \mathrm{~mm})$ E.coli $(03 \pm 0.1 \mathrm{~mm})$, B. subtilis , $P$. aeruginosa and $K$. pneumonia also no zone of inhibition, and the flower sample showed inhibitory activity against $S$. aureus $(11 \pm 0.2 \mathrm{~mm})$ E.coli $(02 \pm 0.2 \mathrm{~mm}), B$.cereus $(02 \pm 0.2 \mathrm{~mm}), P$. auriginosa, (09 $\pm 0.3 \mathrm{~mm})$, K. pneumonia (08 \pm 0.2 $\mathrm{mm})$. Overall the leaf extract showed highly sensitivity against $S$. aureus as shown in Table 2 and Fig. 4.

Minimum inhibitory concentration (MIC)

Tube dilution assay: The tube dilution assay for MIC of the various extracts in terms of change in color of the tubes after addition of resazurin dye against the test strain Staphylococcus aureus are presented in table 3.

The growth of $S$. aureus was inhibited at $100 \mathrm{mg}$, $50 \mathrm{mg}, 25 \mathrm{mg}$ and $12.5 \mathrm{mg}$ concentration of leaf and flower in the first to fourth tubes and showed no turbidity; and in stem concentration of $100 \mathrm{mg}$, $50 \mathrm{mg}, 25 \mathrm{mg}$ showed no turbidity. Based on visual inspection it is claimed that $100 \mathrm{mg}, 50 \mathrm{mg}, 25 \mathrm{mg}$ and $12.5 \mathrm{mg}$ would be the minimum inhibitory concentration (MIC) against $S$. aureus. For further confirmation of a bacterial growth inhibition resazurin dye $(20 \mu \mathrm{l})$ was added as a growth indicator to tubes showing reduction of bacterial growth based

Table 1. Phytochemical constituents of $A$. lanata.

\begin{tabular}{|c|c|c|c|c|c|}
\hline S.N. & Phytochemical constituents & Name of the test & Leaf & Stem & Flower \\
\hline 1 & Carbohydrates & Benedict's test & - & - & - \\
\hline 2 & Carbohydrates & Fehling's test & - & + & - \\
\hline 3 & Carbohydrates & Barfoed's test & - & + & - \\
\hline 4 & Aminoacids & Ninhydrin test & - & - & + \\
\hline 5 & proteins & Biuret test & - & - & - \\
\hline 6 & Alkaloids & Wagner's test & - & + & + \\
\hline 7 & Alkaloids & Dragendorff's test & - & - & - \\
\hline 8 & Flavonoids & Lead acetate test & + & + & + \\
\hline 9 & Phenol & Ferric chloride test & + & - & - \\
\hline 10 & phenol & Lead acetate test & + & + & + \\
\hline 11 & Tannin & Tannin test & - & - & - \\
\hline 12 & Saponin & Saponin test & - & - & - \\
\hline 13 & Terpenoids & Terpenoids test & - & + & + \\
\hline 14 & cocumarins & Cocumarins test & - & + & - \\
\hline
\end{tabular}




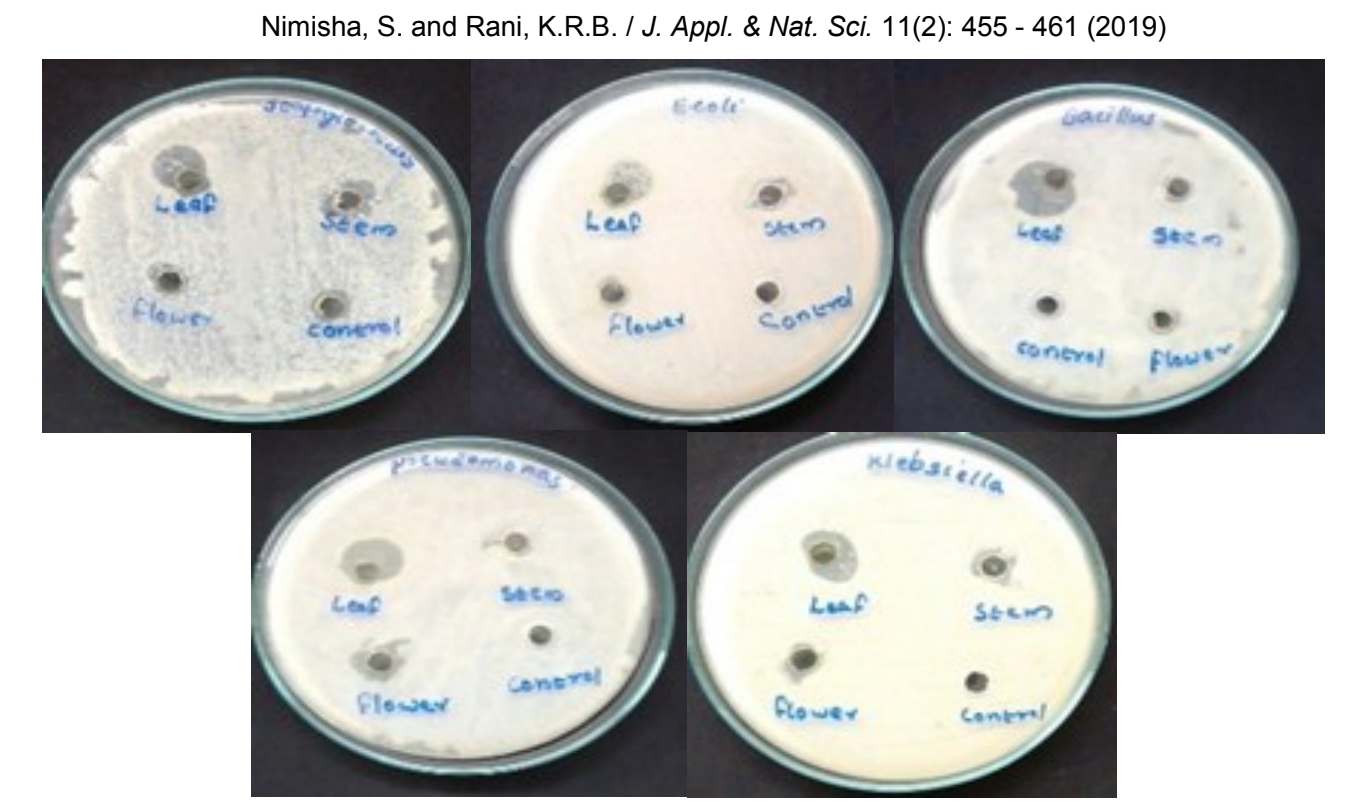

Fig. 4. Antibacterial activity of extracts of different parts of A. lanata.

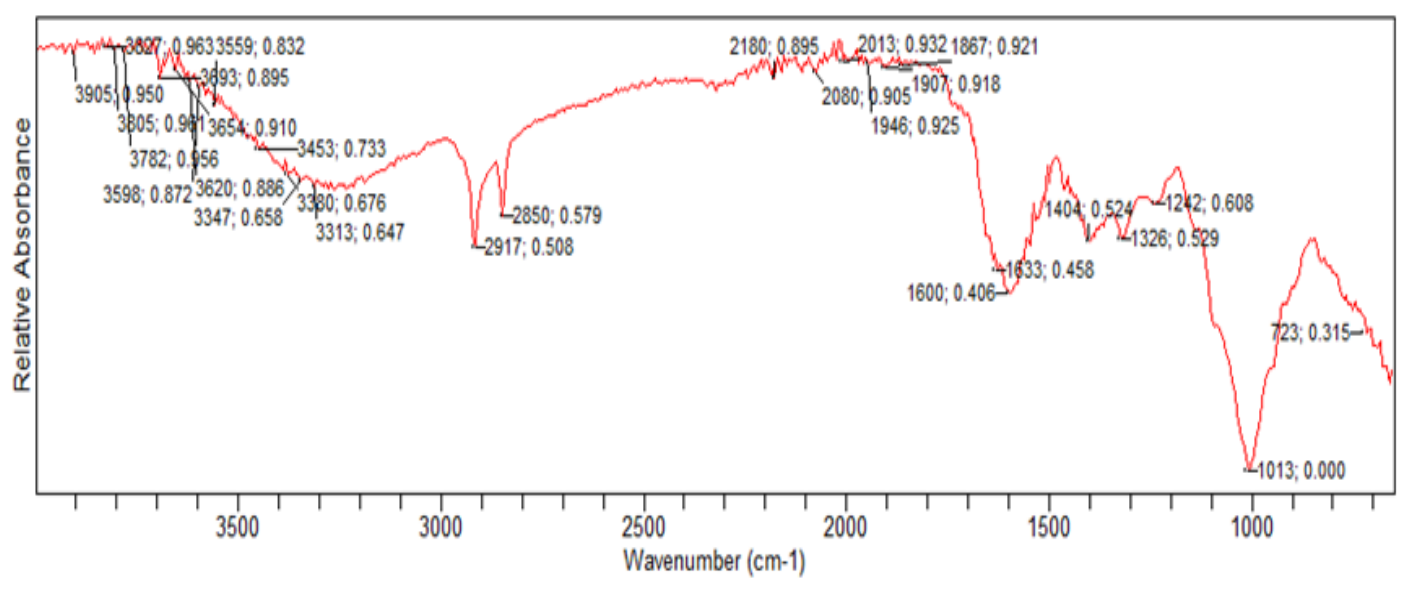

Fig. 5. FTIR analysis of A. lanata -leaf.

Table 2. Antimicrobial activity of $A$. lanata.

\begin{tabular}{lllll}
\hline \multirow{2}{*}{ S.N. } & \multirow{2}{*}{ Bacterial Strains } & \multicolumn{3}{l}{ Zone of inhibition(mm) } \\
\cline { 3 - 5 } & & Leaf & Stem & Flower \\
\hline 1. & Staphylococcus aureus & $16 \pm 0.2$ & $11 \pm 0.3$ & $11 \pm 0.2$ \\
2. & Escherichia coli & $14 \pm 0.2$ & $3 \pm 0.1$ & $2 \pm 0.2$ \\
3. & Bacillus subtilis & $12 \pm 0.5$ & No zone & $2 \pm 0.2$ \\
4. & Pseudomonas aeruginosa & $11 \pm 0.2$ & No zone & $9 \pm 0.3$ \\
5. & Klebsiella pneumoniae & $8 \pm 0.2$ & No zone & $8 \pm 0.2$ \\
\hline
\end{tabular}

Table 3. MIC of different extracts of $A$. lanata.

\begin{tabular}{|c|c|c|c|c|c|c|c|c|c|c|c|}
\hline \multirow{2}{*}{$\begin{array}{l}\text { Bacterial } \\
\text { strain }\end{array}$} & \multirow{2}{*}{$\begin{array}{l}\text { Plant } \\
\text { extract }\end{array}$} & \multicolumn{10}{|c|}{ Plant extract concentration $(\mathrm{mg} / \mathrm{ml})$} \\
\hline & & 100 & 50 & 25 & 12.25 & 6.12 & 3.06 & 1.53 & 0.76 & control & 100 \\
\hline \multirow{3}{*}{$\begin{array}{l}\text { Staphylococ- } \\
\text { cus aureus }\end{array}$} & Leaf & + & + & + & + & - & - & - & - & No turbidity & No turbidity \\
\hline & Stem & + & + & + & - & - & - & - & - & No turbidity & No turbidity \\
\hline & Flower & + & + & + & + & - & - & - & - & No turbidity & No turbidity \\
\hline
\end{tabular}

\section{+ Absence of turbidity ; - Presence of turbidity}

on turbidity. The pink color was indicative of presence of bacterial growth and blue color showed inhibition of bacterial growth. Here in leaf and stem extracts of first to fourth tubes showing blue color and rest of the concentration showed pink color indicating bacterial growth.

Fourier transform infrared spectroscopy (FTIR): In the leaf extract of $A$. lanata, 28 functional groups were observed. The peak values were $1013 \mathrm{~cm}^{-1}, 723 \mathrm{~cm}^{-1}, 1242 \mathrm{~cm}^{-1}, 1326 \mathrm{~cm}^{-1}, 1404$ 
Table 4. FTIR-functional group of leaf of $A$. lanata.

\begin{tabular}{lll}
\hline S.N. & Group & $\begin{array}{l}\text { Stretching } \\
\text { frequency }\end{array}$ \\
\hline 1 & $\mathrm{C}-\mathrm{F}$ & 1013 \\
2 & $\mathrm{C}-\mathrm{Br}$ & 723 \\
3 & $\mathrm{C}-\mathrm{N}$ stretching & 1242 \\
4 & $\mathrm{C}-\mathrm{N}$ stretching & 1326 \\
5 & $\mathrm{~S}=\mathrm{O}$ stretching & 1404 \\
6 & $\mathrm{C}=\mathrm{C}$ alkene & 1633 \\
7 & $\mathrm{C}=\mathrm{C}$ aromatic & 1600 \\
8 & Alkyne $\mathrm{C}-\mathrm{H}$ & 2180 \\
9 & Alkane $(\mathrm{C}-\mathrm{H})$ & 2850 \\
10 & Alkane $\mathrm{C}-\mathrm{H})$ & 2917 \\
11 & Amine N-H & 3313 \\
12 & Amine N-H & 3380 \\
13 & Amine N-H & 3347 \\
14 & $\mathrm{O}-\mathrm{H}$ stretching & 3782 \\
15 & $\mathrm{O}-\mathrm{H}$ stretching & 3620 \\
16 & $\mathrm{O}-\mathrm{H}$ stretching & 3589 \\
17 & $\mathrm{O}-\mathrm{H}$ stretching & 3654 \\
18 & $\mathrm{O}-\mathrm{H}$ stretching & 3693 \\
19 & $\mathrm{O}-\mathrm{H}$ stretching & 3559 \\
20 & Alcohol C $-\mathrm{O}$ & 3453 \\
21 & $\mathrm{C}-\mathrm{H}$ bending & 1867 \\
22 & $\mathrm{C}-\mathrm{H}$ bending & 1907 \\
23 & $\mathrm{C}-\mathrm{H}$ bending & 1946 \\
24 & $\mathrm{~N}=\mathrm{C}=\mathrm{S}$ stretching & 2080 \\
25 & $\mathrm{~N}=\mathrm{C}=\mathrm{S}$ stretching & 2013 \\
26 & $\mathrm{O}-\mathrm{H}$ alcohol & 3805 \\
27 & $\mathrm{NH}$ amine & 3905 \\
28 & $\mathrm{NH}$ amine & 3827 \\
\hline
\end{tabular}

$\mathrm{cm}^{-1}, 1633 \mathrm{~cm}^{-1}, 1600 \mathrm{~cm}^{-1}, 2180 \mathrm{~cm}^{-1}, 2850 \mathrm{~cm}^{-1}$, $2917 \mathrm{~cm}^{-1}, 1867 \mathrm{~cm}^{-1}, 1907 \mathrm{~cm}^{-1}, 1946 \mathrm{~cm}^{-1}, 2080$ $\mathrm{cm}^{-1}$, and $2013 \mathrm{~cm}^{-1}, 3313 \mathrm{~cm}^{-1}, 3380 \mathrm{~cm}^{-1}, 3347$ $\mathrm{cm}^{-1}, 3782 \mathrm{~cm}^{-1}, 3453 \mathrm{~cm}^{-1}, 3620 \mathrm{~cm}^{-1}, 3598 \mathrm{~cm}^{-1}$, $3654 \mathrm{~cm}^{-1}, 3693 \mathrm{~cm}^{-1}, 3559 \mathrm{~cm}^{-1}, 3805 \mathrm{~cm}^{-1}, 3905$ $\mathrm{cm}^{-1}, 3827 \mathrm{~cm}^{-1}$ (Fig. 5). The appropriate class of functional groups and its stretching frequency are given in Table 4.

Gas chromatography coupled with mass spectrometry: The phytochemical constituents present in plant $A$. lanata identified by gas chromatography coupled with mass spectrometry showed that the ethanol leaf extract of contained 27 phytochemical components (Fig. 6 and Table 5). The major components were Uridine $(38.94 \%)$, Batilol $(14.80 \%)$, Friedelan (10.91\%), Adenosine (8.66\%), 2-tetrahrdrofurylmethyl ester(6.55\%), Ledene oxide(5.71\%), Tetrahydro(3.05\%), methyl $(2.09 \%)$, propanetriol(1.56\%), Iso-valeraldehyde (0.89\%), Isopropyl (0.83\%), Epoxy $(0.74 \%)$, 9Octadecenal $(0.71 \%)$, Methyl octyl ether $(0.70 \%)$, Isocyclocitral $(0.54 \%)$,Alpha-methyl-alpha(0.48\%), Batiloloctadecylether $\quad(0.44 \%)$,Cedrene $(0.39 \%)$, Tetraphenylhydrazine $(0.34 \%)$, Cysteine $(0.31 \%)$, $\mathrm{N}$-Acetyl $(0.27 \%)$, 2-Aminomethyl $(0.25 \%)$, Verrucarol $(0.24 \%)$, Pyridol(0.22\%), Picrotoxin $(0.21 \%)$, D-Alanine $(0.16 \%)$, 4-Methyleneproline $(0.02 \%)$. This results showed that the major compounds possess the following biological activities viz., antibacterial, antineoplastic, antiviral, anticarcinogenic, antiurolithic, anti-inflammatory, antiseptic, antitoxic, antihelmintic properties.

\section{DISCUSSION}

Antibacterial activity of A.lanata plant extract was observed against some pathogenic bacteria which possess increased activities. Earlier studies revealed $A$. lanata extracts of leaf, stem flower and root extracts possess different medicinal properties viz, antimicrobial activity, antidiabetic activity, antioxidant activity (Kumar et al., 2013). Recently many solvents such as ethanol, ethyl acetate, chloroform, acetone, water and methanol were administered for different phytochemical analysis and established the occurrence of flavonoids, glycosides, tannins, steroids, saponins, phenolics, terpenoids and alkaloid hold constituents were employed for the screening of phytochemical constituents (Ramana et al.,2015). In the present investigation we used the ethanol as solvent sources for the extraction of the metabolites. From table 1, it is clear that the chemical constituents of $A$. lanata are flavonoids, phenols, carbohydrates, aminoacids, terpenoids and cocu-

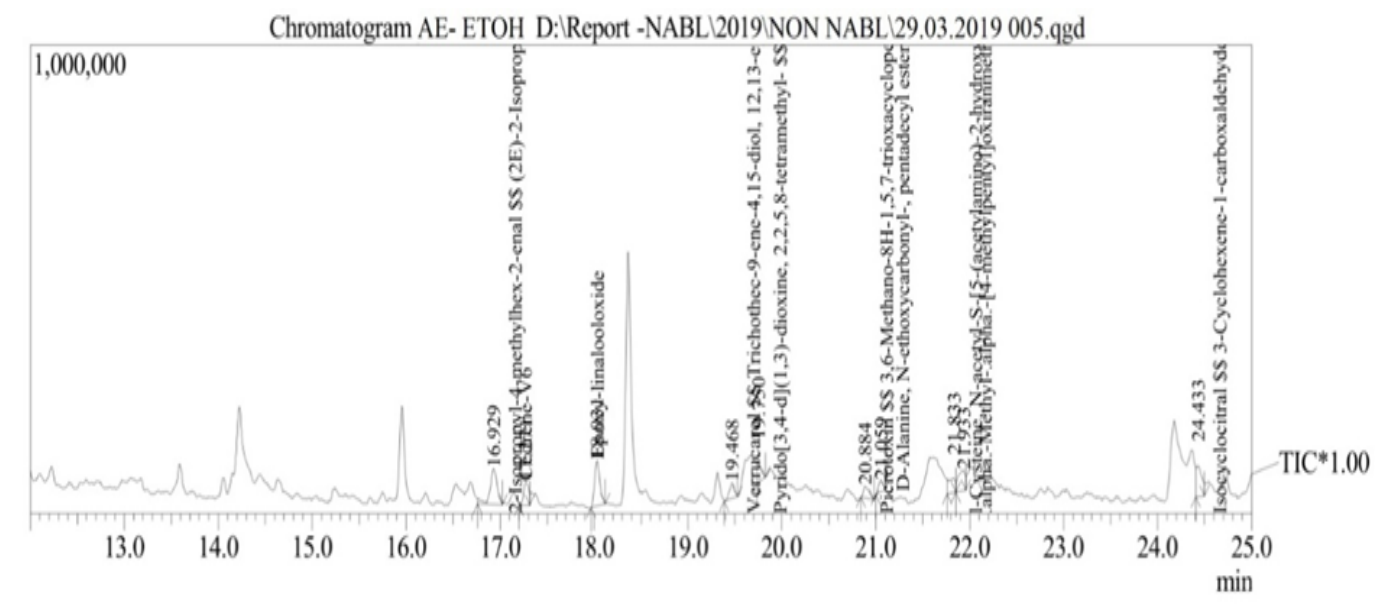

Fig. 6. Gas chromatography coupled with mass spectrometry of leaf of A.lanata. 
Table 5. Gas chromatography coupled with mass spectrometry of leaf of $A$. lanata.

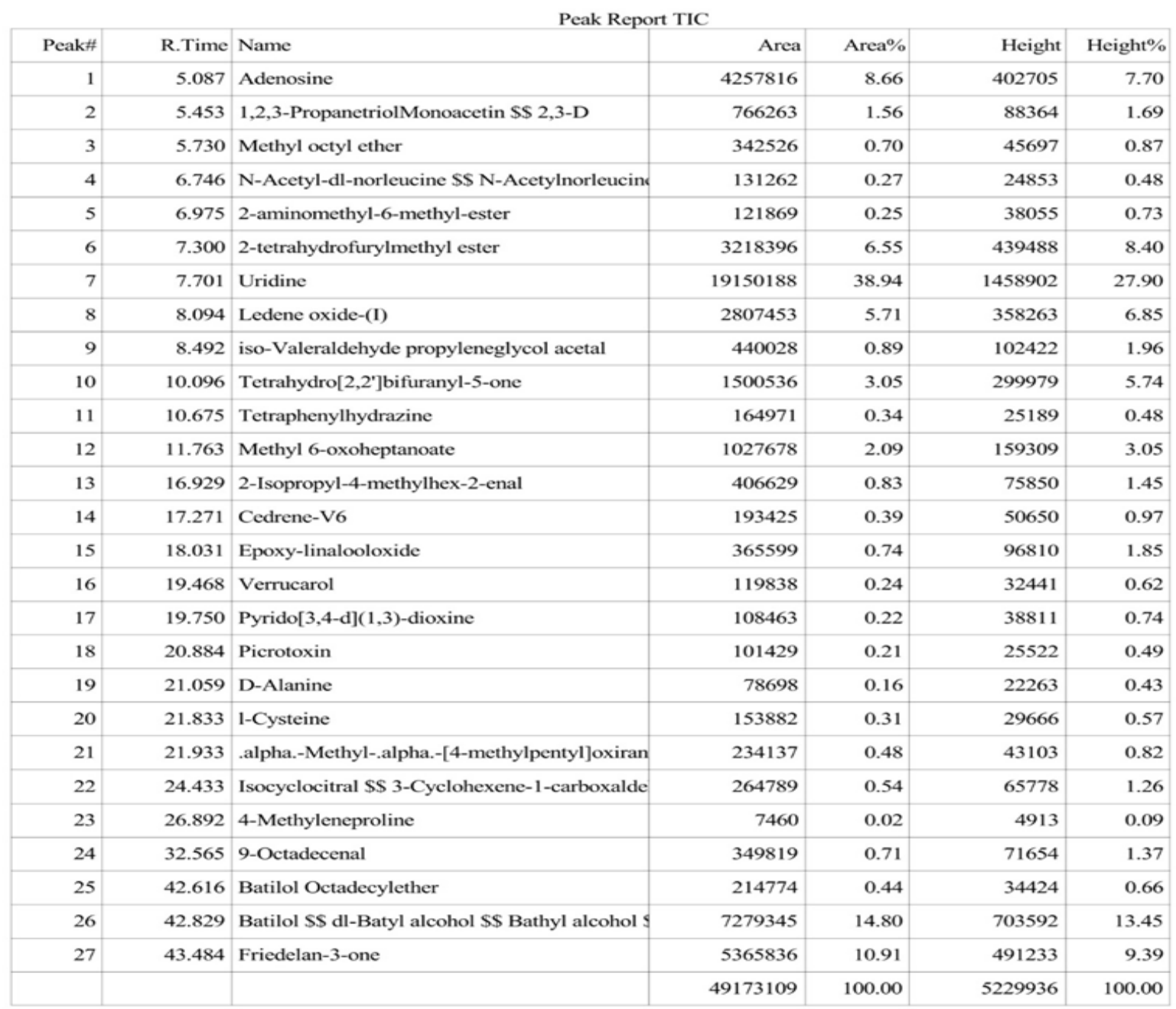

marins which serve as a main pharmaceutical product in curing ulcers, kidney stone, jaundice, head ache, stomatitis, fever, pain in liver, wounds in cattle, treatment of oedema and rheumatic joint pains etc.

The antibacterial property of the leaf extract revealed extreme sensitivity on $S$. aureus $(16 \mathrm{~mm})$, an prime cause of human infections and several illness by means of upper respiratory tract infection and skin infection etc. and it is also a chief cause of food poisoning. The minimum inhibitory concentration of leaf, flower showed inhibition on has first four tubes and in stem extract first three tubes showed inhibition and this findings revealed that this particular plant has high medicinal properties.

Based on the property of antibacterial activity, spectroscopic analysis carried out only in leaf extract of $A$. lanata showed more peaks of $\mathrm{O}-\mathrm{H}$ stretching. Each peak indicated the phytochemical compound in the leaf extract. The FT-IR spectrum analysis of leaf powder of $A$. lanata showed that the existence of divergent functional groups vary from $\mathrm{O}-\mathrm{H}$ stretching $\left(3782 \mathrm{~cm}^{-1}, 3693 \mathrm{~cm}^{-1}\right.$, $\left.3654 \mathrm{~cm}^{-1}, 3620 \mathrm{~cm}^{-1}, 3598 \mathrm{~cm}^{-1}, 3559 \mathrm{~cm}^{-1}\right)$, amine $\mathrm{N}-\mathrm{H}\left(3380 \mathrm{~cm}^{-1}, 3347 \mathrm{~cm}^{-1}, 3313 \mathrm{~cm}^{-1}\right)$ alkane $(\mathrm{C}-\mathrm{H})\left(2917 \mathrm{~cm}^{-1}, 2850 \mathrm{~cm}^{-1}\right), \mathrm{N}=\mathrm{C}=\mathrm{S}$ stretching $\left(2080 \mathrm{~cm}^{-1}, 2013 \mathrm{~cm}^{-1}\right), \mathrm{C}-\mathrm{H}$ bending $\left(1946 \mathrm{~cm}^{-1}, 1907 \mathrm{~cm}^{-1}, 1867 \mathrm{~cm}^{-1}\right), \mathrm{C}=\mathrm{C}$ alkene $\left(1404 \mathrm{~cm}^{-1}\right), \mathrm{C}-\mathrm{N}$ stretching $\left(1326 \mathrm{~cm}^{-1}, 1242 \mathrm{~cm}\right.$ $\left.{ }^{-1}\right), C-F\left(1013 \mathrm{~cm}^{-1}\right), C-B r\left(723 \mathrm{~cm}^{-1}\right)$.

Yamunadevi Mariswamy et al.,(2013) reported that the GC-MS analysis of methanol extract of whole plant of A.lanata has 23 different phytochemical compounds. The acetone extract of A.lanata leaves showed 16 bioactive compounds (Arun Thangavel et al., 2014). Venaktesh Prasad yadav et al.,(2019) reported the elevated parts of ethanolic extract of A.lanata revealed total 76 bioactive compounds, in that 40 known compounds which shows medicinal properties and 36 unknown compounds. In present study, total 27 bioactive compounds were isolated from the leaf extract of $A$. lanata in that, Uridine $(38.94 \%)$ is a major compound, followed by other compounds (Table 5) which shows antiallergic, anti- 
inflammatory, antimicrobial and anticancer activity as reported by Yamunadevi et al.,(2013), Arun Thangavel et al., (2014), Venaktesh Prasad yadav et al. (2019)) for alzheimer's disease, gaucher disease treatment, cystic fibrosis treatment, sickle-cell anemia treatment, cardiac treatment, rheumatoid arthritis etc.

This study suggests boundless activity for the major constituents of the ethanolic extracts of $A$. lanata leaves, flower and stem. The current research indicated that the ethanolic extract of leaf is a powerful remedial agent for many diseases. Because it is comparatively secure and can be used to dissolve many organic compounds and it contains polar $\mathrm{O}-\mathrm{H}$ bond hence it is soluble in water. Additional requirement is involved to separate and recognize these bioactive compounds. For recognizing these bioactive compounds novel medicines can be developed to manage different ailments. The results of the current findings also supplemented with previous researchers.

\section{Conclusion}

To conclude from this investigation the ethanolic extracts of leaf, stem and flower can act as a good antibacterial activity and also good nutritive importance. The Spectroscopic analysis of $A$. lanata leaves showed 27 bioactive compounds with known medicinal properties. Identification of these bioactive compounds may serve as the possible health benefits to formulate new drugs with fewer side effects.

\section{REFERENCES}

1. Arun Thangavel, and Balakrishnan, Senthilkumar and Aarthy, Arumugam and Duraisamy, Senbagam and Muthusamy, Sureshkumar. (2014). Phytochemical screening, gas chromatography-mass spectrometry (GC-MS) analysis of phytochemical constituents and anti-bacterial activity of Aerva lanata (L.) leaves. African Journal of Pharmacy and Pharmacology. 8. 126-135. 10.5897/AJPP2013.3969.

2. Das S., M. Borah and S. Ahmed (2013) Antibacterial activity of the ethanolic extract of leaves of Citrus maxima (Burm.) Merr.Escherichia coli and Pseudomonas aeruginosa.Asian Journal of Pharmaceutical and Clinical Research., 6(4): 136-139.

3. Desai A. G., Qazi G. N., Ganju R.K. , El-Tamer M, Singh J, Saxena AK, Bedi YS, Taneja SC, Bhat HK (2008). Medicinal plants and cancer chemopreven- tion. Curr Drug Metab., 9: 581-591.

4. Gullo VP, Hughes DE (2005). Exploiting new approaches for natural product drug discovery in the biotechnology industry. Drug Discov Today Techno.I, 2(3): $281-286$

5. Harborne AJ (1998). Phytochemical Methods A Guide to Modern Techniques of Plant Analysis. 3rd ed. Springer, Netherlands. p.302.

6. Krishnaiah D, Sarbatly R, Bono A (2007). Phytochemical antioxidants for health and medicine: A move towards nature. Biotechanol Mol Biol Rev., 1 (4): $97-104$

7. Krishnamoorthi R (2015). Phytochemical analysis and antioxidant property of Aerva lanata. International journal of pharmacognosy, 2(8): 426-429.

8. Kumar G, Karthik L, Rao. K. V. (2013). Phytochemical composition and in vitro antioxidant activity of aqueous extract of Aerva lanata (L.) Juss. ex Schult. Stem (Amaranthaceae) Asian Pacific J. Trop. Med. pp. 180-187.

9. Muthukumaran, P., Shanmuganathan P., Malathi, C. (2011). Antioxidative and Antimicrobial Study of Aerva lanata. Asian Journal of Biochemical and Pharmaceutical Research, 1(2).265-271.

10.Nostro, A., Germano, M.P., D"Angelo, V., Marino, A., Cannatelli, M. A. (2000). Extraction methods and bioautography for evaluation of medicinal plant antimicrobial activity. Lett Microbiol., 30(1): 379-384.

11.Pavithra, S., Janani, P.S., Charumathi, V. H., Indumathy, K., Potala, Sirisha R. and Verma, Rama. (2010). Antibacterial activity of plants used in Indian herbal medicine. International Journal of Green Pharmacy. DOI. 4. 10.4103/0973-8258.62161.

12.Ramana K. V., Vikram, G. (2015). Aerva lanata a potentially useful medicinal plant. Medicinal Plant Research, 5 (4) : 1-4.

13.Sofowora, A. (1993). Medicinal Plants and Traditional Medicine in Africa.Spectrum Books Ltd., Ibadan, Nigeria, pp. 191-289.

14.Venaktesh Prasad Yadav L., Ashwathanarayana, R. L., Padmashree, M. S. (2019). Study on gas chromatography and mass spectroscopy analysis, antioxidant, and nutritive properties of aerva lanata (I.) Juss. Collected from selected regions of Shimoga, Karnataka, India. Asian J Pharm Clin Res., 12 (2): 185-195

15.Vijaya Kumar R, Pulliah T (1998). Medicinal plants used by tribals of Prakasm district, Andhra Pradesh. Ethanobotany, 10:97-102.

16. Yamunadevi Mariswamy., Edward Gnanaraj, Wesely, Marimuthu Alias Antonisamy, Johnson , Arockiaraj Adaikalam, Anto and Vinnarasi, J. (2013). GC-MS Studies on Methanolic Extracts of Aerva lanata L. Indo American Journal of Pharm Research, 3:3 